\title{
Cerebralis hyperperfusiós szindróma és vérnyomáskontroll
}

\author{
Fazekas Gábor dr. - Kasza Gábor dr. - Arató Endre dr. \\ Sínay László dr. - Vadász Gergely dr. - Füzi Árpád dr. - Hardi Péter dr. \\ Benkő László dr. - Nagy Tibor dr. - Jancsó Gábor dr. - Menyhei Gábor dr.
}

Pécsi Tudományegyetem, Általános Orvostudományi Kar, Klinikai Központ, Érsebészeti Klinika

\begin{abstract}
Bevezetés: A cerebralis hyperperfusiós szindróma ritka, kevéssé ismert kórkép, amely azonban olykor súlyos következményekkel járhat. Felléphet a carotis mütéti revascularisatióját vagy stentelését követően is. Jellegzetes tüneteinek felismerése (fejfájás, görcs, fokális neurológiai deficit), a képalkotó vizsgálatok (ultrahang, komputertomográfia) mielőbbi elvégzése döntő jelentőségü a kórismézés szempontjából. Célkitüzés: A nemzetközi irodalmat és a szerzők saját betegeinek adatait áttekintve a tünetegyüttes kialakulására nézve veszélyeztetett csoport kiszűrése, effektív terápiás protokoll felállítása. Módszer: A szerző́k osztályán kezelt betegek dokumentumait 2010-tő́l napjainkig retrospektíve áttekintve, mindeddig 3 esetben találkoztak a kritériumoknak megfelelő fenti tünetegyüttessel. Eredmények: Mindhárom esetben hasonló elvek mentén, intenzív osztály közremúködésével avatkoztak közbe, azonban a közbelépés csak egy esetben volt hatékony, megfelelő terápiával gyors remisszió volt elérhető. Következtetések: Egyelőre, sajnos, nem áll rendelkezésre olyan diagnosztikai eszköz, amellyel hatékonyan és egyértelmúen kiszürhetők a kockázati csoportok, így megelőzési lehetőségként az egyetlen gyógyszeresen befolyásolható kockázati tényező, a vérnyomás perioperatív beállítása marad kezünkben. Amennyiben a tünetek mégis kialakulnak, mielóbbi agresszív kezelés szükséges. Orv. Hetil., 2015, 156(26), 1049-1053.
\end{abstract}

Kulcsszavak: carotis, stroke, hyperperfusio, hypertonia

\section{Cerebral hyperperfusion syndrome and blood pressure control}

Introduction: Cerebral hyperperfusion syndrome is a rare, hardly known condition, which can result in serious complications either after surgical or endovascular revascularization. Recognition of the typical triad (headache, seizure, focal neurological deficit) and the prompt radiological diagnosis (sonography, computed tmography) are crucial to achieve a favourable outcome. Aim: The aim of the authors was to select the endangered group and set up an effective therapeutic protocol based their own expereince in combination with relevant literature data. Method: From the beginning of 2010 up to now three cases with these symptoms pursuant to the criteria of cerebral hyperperfusion syndrome have been recognized by the authors. Results: Each of the three patients were treated by similar principles on intensive care unit, but the applied therapy resulted in complete remission in one patient only. Conclusions: At present there is no efficient diagnostic way to screen the endangered group, hence the only opportunity for prevention is the appropriate perioperative blood pressure control. If symptoms have developed already, urgent treatment is required.

Keywords: carotis, stroke, hyperperfusion, hypertension

Fazekas, G., Kasza, G., Arató, E., Sinay, L., Vadász, G., Füzi, Á., Hardi, P., Benkö, L., Nagy, T., Jancsó, G., Menyhei, G. [Cerebral hyperperfusion syndrome and blood pressure control]. Orv. Hetil., 2015, 156(26), 10491053.

(Beérkezett: 2015. március 23.; elfogadva: 2015. április 30.)

\begin{abstract}
Rövidítések
ACI $=$ arteria carotis interna $\mathrm{ACM}=$ arteria cerebri media; $\mathrm{CEA}=$ carotisendarterectomia $; \mathrm{CHS}=$ cerebralis hyperperfusi ós szindróma; $\mathrm{ICH}=$ intracerebralis haemorrhagia; $\mathrm{LMWH}=$ kis molekulasúlyú heparin
\end{abstract}

Az összes ischaemiás stroke-os megbetegedés mintegy 15-20\%-áért az arteria carotis interna (ACI) extracranialis szakaszának szúküulete tehető felelőssé $[1,2]$. Ezen agyi történések kialakulásának széles körben elterjedt, hatásos, hosszú távon is kiváló eredményeket mutató 
módszere a carotisendarterectomia (CEA) [1, 2, 3]. A rendelkezésre álló randomizált, kontrollált tanulmányok tisztázták az indikációs kört [3]. Tünetmentes esetben endarterectomia végzendő $70 \%$-ot meghaladó stenosis esetén [3]. Tünetes esetben, bizonyos plakkmorfológia (instabil, lágy, ulcerogén) esetén már 50\%-os szúkület felett javasolt a mütét elvégzése, lehetőség szerint két héten belül [3]. Szintén effektív stroke-prevenció érhető el endovascularis módszerrel [3]. Azonban összehasonlító tanulmányok adatai alapján a magasabb stroke-rizikó és restenosisarány miatt a stentimplantáció indikációs köre leszúkült, így elsőként továbbra is a mütéti eljárás elvégzése javasolt [3] (1. táblázat). A CEA-t követő, hazánkban 2,5-5\%-ban előforduló neurológiai szövődmények döntően ischaemiás eredetüek, okuk embolisatio vagy az ACI elzáródása $[1,4]$ (1. ábra). Míg ezekben az esetekben a kialakuló neurológiai tünetekért obliteratív folyamatok felelősek, addig a betegek egy igen kis csoportjában pont ellenkezőleg, a beavatkozást (mútét vagy stentelés) követő re-, hyperperfusio okozza a kialakuló szimptómákat $[1,5]$.

1. táblázat |A carotisstentelés indikációs köre [3]

Korábbi nyaki műtét.

Irradiáció a nyakon.

Magasra terjedő stenosis.

Magas bifurcatio.

Mütétet követő restenosis.

Ellenoldali nervus laryngeus recurrens bénulás.

Magas kockázatú beteg.

\section{Posztoperatív stroke/TIA arány}

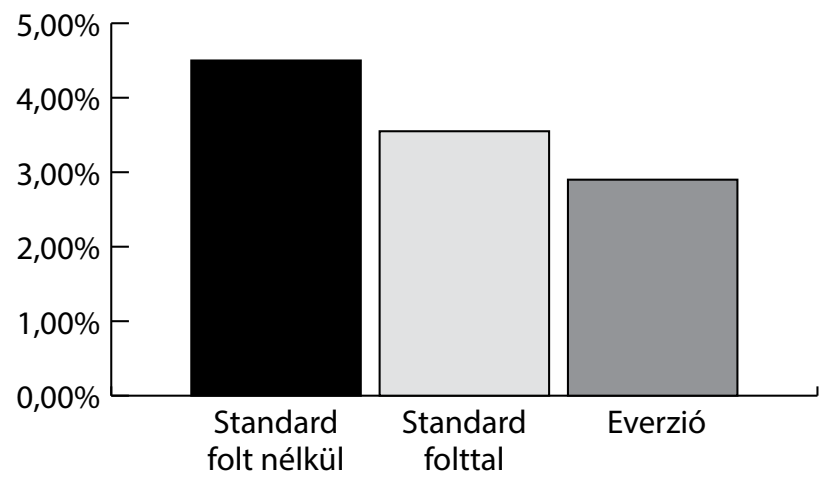

1. ábra

| Magyarországi carotisregiszter-adatok $(\mathrm{N}=4495)$ [4]

A cerebralis hyperperfusiós szindrómát először 1964 ben írták le $[1,6]$, azóta számos esettanulmányt, cikket közöltek a témában. Jelentősége a felismerés fontosságában rejlik, ugyanis jelen ismereteink alapján egyelőre biztonsággal nem megelőzhető, késői felismerés esetén pedig akár halálos kimenetel is lehetséges $[1,7]$. Nem- zetközi szakirodalmi adatok alapján incidenciája 1-3\% között mozog $[1,8,9]$, amit a rendelkezésünkre álló retrospektív adatok is alátámasztanak.

Jellegzetes triásszal jellemezhetjük a kórképet: féloldali fejájás, fokális neurológiai deficit, görcsroham (lehet fokális vagy generalizált) $[1,5,9,10]$. A tünetek a beavatkozást követő 30 napon belül bármikor, külön-külön is megjelenhetnek $[1,5,9,10]$, bármelyikük fellépte óvatosságra, azonnali vizsgálódásra ad okot. A szindróma igazolására képalkotóval bizonyítani kell a carotis nyitott voltát, az új keletû cerebralis ischaemia hiányát, illetve az ipsilateralis agyödémát vagy intracerebralis haemorrhagiát $(\mathrm{ICH})[1,5,9,10]$. Minden esetben ki kell zárni az esetleges metabolikus, farmakológiai hatásokat [9].

Pontosan a ritka előfordulás és alacsony esetszám miatti csekély adatmennyiségből, illetve a betegség etiológiájának összetettségéből fakad a kórkép jelentősége. Felismerésének bonyolultsága kifejezett nehézséget jelent. A kockázati csoport kiszúrése rendkívül fontos, és az ebbe a csoportba tartozó betegek esetében agresszívebb posztoperatív antihipertenzív terápiára lenne szükség.

\section{Módszer}

Osztályunkon évente átlagban 80-90 carotisendarterectomiát végzünk, megközelítőleg fele-fele arányban választjuk az everziót és a TEA+foltplasztika módszerét, ez utóbbi a distalis intimalépcső biztonságosabb ellátását teszi lehetővé. Minden beteg mind a mútétet megelőző, mind az azt követő időszakban thrombocytaaggregációgátló és statinkezelésben részesül. Míg a klopidogrél szedését minden esetben felfüggesztjük, addig az aszpirin adása folyamatos a perioperatív időszakban. Antibiotikus profilaxisként $1 \mathrm{~g}$ cefazolint adunk intravénásan, egyszeri dózisban. A folyamatos neuromonitoring előnye miatt intézetünkben a perioperatív stroke-előfordulás szempontjából a narkózissal egyenértékú lokoregionális anesztéziát [11] részesítjük előnyben. A 3 perces próbakirekesztés során észlelt neurológiai tünet esetén a mútétet söntkeringésben folytatjuk. Posztoperatív időszakban a betegeket 24-36 órán át intenzív osztályon monitorozzuk, 10 napig kis molekulasúlyú heparin- (LMWH-) profilaxisban részesítjük.

2010-től kezdődően 2014 első negyedévével bezárólag retrospektíven elemeztük az osztályunkra mútét céljából felvett, illetve a mütétet követően az intenzív osztályon kezelt betegeink anyagát. Ezen időszakban 348 mútétet végeztünk a fent említett módszerek valamelyikével.

\section{Eredmények}

A dokumentációt áttekintve 3 betegnél találtunk a kritériumoknak megfelelő, CT-vel igazolt CHS-t. 
Első betegünk tünetmentes, szignifikáns ACI-stenosis miatt (enyhe fokú ellenoldali stenosis mellett) került mütétre. Posztoperatív időszakban jelentkező igen magas, 240-260 Hgmm közötti vérnyomásértékek mellett másnap reggelre erős, féloldali fejfájás alakult ki, amely eredményes antihipertenzív terápiára szúnt. Ismert hyperthyreosisa miatt az intenzív osztályról az endokrinológiai osztályra került gyógyszeres beállítás céljából; itt észlelték a mütét utáni 5. napon az ismételten magas, 190 Hgmm-es vérnyomáshoz társuló szótalálási nehézségét. A készült duplex scan nyitott carotiságrendszert mutatott, a koponya-CT féloldali agyödémát írt le ischaemiás laesio, állományi vérzés nélkül. A megfelelő terápia beállítását követően a tünetek néhány nap alatt maradéktalanul megszüntek, a beteg a mai napig panaszmentes.

Második esetben végzetes volt a kimenetel. Szintén tünetmentes, szignifikáns stenosissal (ellenoldali jelentős stenosis mellett) mütétre kerülő betegnél a közvetlen posztoperatív szakban uralhatatlan, maximálisan 250 Hgmm-es szisztolés vérnyomás jelentkezett, amelyet hemiparesis, motoros afázia kialakulása követett. Képalkotók közül a duplex reokklúziót nem mutatott, azonban a CT-n a féltekei ödéma mellett, kamrába törő intracerebralis haemorrhagia igazolódott. A beteg fokozatosan romló cardiopulmonalis állapota, progrediáló neurológiai státusa a mútét utáni 3 . napon exitushoz vezetett.

Harmadik betegünk TIA-t követően, amelynek hátterében szubtotális stenosis igazolódott az ellenoldali szignifikáns stenosis mellett, két héten belül mütőasztalra került. A közvetlen posztoperatív szak eseménytelen volt, azonban emissziójának napján (posztoperatív 5. nap) kiugró vérnyomáshoz (180 Hgmm) társultan észleltük friss neurológiai deficit (súlyos hemitünetek, dysarthria) kialakulását. Nyitott carotiságrendszer, CT-n kamrákba törő állományi vérzés igazolódott. A beteg neurológiai státusa lassan progrediált, majd mútét után 7 héttel a neurológiai intenzív osztályon meghalt.

Fentieken felül további három, közvetlen posztoperatív vérnyomáskiugráshoz társult esettel találkoztunk. Egy esetben erős féloldali fejfájás, két esetben felső végtagi gyengeség, illetve facialis paresis jelentkezett, amelyek felvetik a cerebralis hyperperfusiós szindróma (CHS) kóroki szerepét, azonban a megfelelő terápia hatására gyorsan szanálódó tünetek miatt képalkotó nem készült, így a szindróma nem került igazolásra.

\section{Megbeszélés}

Mindenekelőtt szükséges magának a hyperperfusiónak a definiálása, hiszen minden egyes revascularisatiót követően növekszik az agyi vérátáramlás, azonban hyperperfusióról csak az agyi vérátáramlás 100\%-ot meghaladó növekedése esetén beszélhetünk $[1,5,8]$. Az összes eset 10\%-ában megjelenik hyperperfusio, ellenben ezeknek csak kis hányada okoz tüneteket $[1,10]$. Ha a hyperperfusióhoz társultan nyitott carotis mellett a jellegzetes tünetek is megjelennek és az új keletû cerebralis ischaemia is kizárható, beszélhetünk a szindróma kialakulásáról [1, $5,9,10]$.

A CHS patomechanizmusát tekintve legfontosabb kóroki tényező az előbbiekben említett hyperperfusio $[1,8]$. A posztoperatív hypertonia szerepe nemcsak az állományi vérzés kockázatának növelésében, de az agyi vérátáramlás, az agyi perfúziós nyomás növelésével a hyperperfusio kialakulásában is kiemelendő [1]. A jelentős mértékű carotisszúkület krónikus hypoperfusio kialakulásához vezet, ennek következtében az agyi autoreguláció - amelynek feladata az agy védelme a vérnyomás-ingadozás káros hatásaitól - elégtelenné válik, így az agyi vérátáramlás és perfúziós nyomás kizárólag a szisztémás vérnyomás függvénye lesz $[1,9,12]$. Ebben az állapotban az agyi kiserek maximálisan dilatáltak, vazoreaktivitásuk csökkent, ennélfogva kifejezetten érzékenyek a vérnyomás hirtelen változásaira [1]. Revascularisatiót követő jelentős tenziónövekedés végzetes következményekkel járhat [1]. Mindehhez hozzájárul az intraoperatív ischaemia alatt felszabaduló oxigén-szabadgyökök károsító hatása, az ischaemiás-reperfusiós károsodások következtében növekedő vazopermeabilitás, sérülő vér agy-gát, valamint a jól ismert receptordenerváció következtében létrejött baroreceptor-diszfunkció, amely kifejezett vérnyomás-emelkedést okozhat [1] (2. táblázat).

2. táblázat | Patofiziológia [1]

\section{Hyperperfusio.}

Posztoperatív hypertensio.

Cerebralis autoreguláció elégtelensége.

Ischaemiás-reperfusiós károsodás, szabad gyökök felszabadulása.

Baroreceptor-diszfunkció.

Megelózésében fontos lenne egy olyan paraméter ismerete vagy képalkotó vizsgálat használata, amellyel nagy biztonsággal kiszűrhetővé válna a kockázati csoport. Biztató eredményeket közöltek az arteria cerebri media (ACM) transcranialis Dopplerrel történő preoperatív áramlásmérése kapcsán $[1,13,14]$. Eszerint mütétet megelőzően az ACI poststenoticus szakaszának alacsony nyomása (<40 Hgmm) és a kirekesztés oldását követően a csúcssebesség 100\%-ot meghaladó növekedése a CHS előrejelzője [1, 13, 14]. Azonban Newman és mtsai nagyszámú beteganyagon felmérve a módszer prediktív értékét, arra jutottak, hogy a 100\%-ot meghaladó csúcssebesség-növekedés és a CHS előfordulása nem mutat szignifikáns relációt; ellenben 100\% alatti érték esetén a CHS kialakulásának esélye csekély [8].

Kiemelten fontosnak tartjuk a mütét időpontjának helyes megválasztását, amelyben az ESVS irányelveihez tartjuk magunkat. Régebbi ajánlásokkal ellentétben mai álláspontunk szerint az ischaemiás tünetektől számított két héten belül elvégzett endarterectomiából profitál 
leginkább a beteg [3]. Fontos emellett kétoldali CEA szükségessége esetén a mútétek időzítése. Ascher és munkatársai tanulmánya nyomán és az általuk tapasztalt hatszoros CHS-rizikó miatt a két mütét között minimum 3 hónap kivárása javasolt [15] (3. táblázat).

3. táblázat | Kockázati tényezők [1]

\begin{tabular}{l} 
Hypertonia. \\
Magas fokú stenosis. \\
Ellenoldali carotisokklúzió. \\
Gyenge kollaterális érrendszer. \\
Csökkent agyi vazoreaktivitás (CVR). \\
Kontralaterális CEA 3 hónapon belül. \\
Distalis intracaroticus nyomás <40 Hgmm. \\
Hosszú intraoperatív ischaemia. \\
\hline
\end{tabular}

A CHS megelózésének és kezelésének alappillére a vérnyomás megfelelő preoperatív beállítása, illetve perioperatív szakban észlelt vérnyomáskiugrás esetén a normotenzió mielőbbi helyreállítása $[1,9]$. A mütétet övező időszakban elterjedten használt szteroid- és mannitolkészítmények hatása CHS-ben kérdéses, alkalmazásuk mellett nem szól evidencia [9, 16, 17]. Mielőtt a beteg mütétre kerülne, fontosnak tartjuk a megfelelő gyógyszeres terápiával elért, stabil vérnyomásértékeket. Ennek elérésére a konvencionális vérnyomáscsökkentők használatosak. Generalizált érbetegek esetében a kedvező cardiovascularis protektív profil miatt a béta-blokkoló bisoprolol adása kifejezetten javasolt, emellett a megfelelő értékek elérésére adhatunk angiotenzinkonvertálóenzimgátlót vagy angiotenzinreceptor-blokkolót, kalciumcsatorna-blokkolót, alfa-receptor-blokkolót, diuretikumot, illetve ezek kombinációját [18]. Ugyanezen kezelés alkalmazható posztoperatív szakban is a magas vérnyomás kezelésére tünetmentes betegeknél. Kerülendők azonban a hagyományos antihipertenzívumok, különösen a nitrátok magas vérnyomáshoz társuló tünetek esetén, mivel fokozzák az agyi perfúziót, ezzel növelik az agyödéma és állományi vérzés veszélyét $[1,9]$ ! Revascularisatiót követően jelentkező szimptómás hypertonia kezelésére az intravénásan alkalmazandó, az agyi vérátáramlást nem emelő szerek preferálandók $[8,9]$ ! Ezek közé tartozik a saját gyakorlatunkban használt centrális szerotoninagonista és perifériás alfa-1-receptor-gátló urapidil (Ebrantyl), amelynek alkalmazásával kapcsolatos tapasztalatok pozitívak, korábban említett esetekben urapidilbázisú antihipertenzív terápiával értünk el sikert. Sok helyen első vonalban ajánlják, klinikánkon csak ritkán alkalmazzuk az alfa- és béta-blokkoló hatással bíró labetalolt $[1,8]$.

Jelenleg, sajnos, nem áll rendelkezésre egyértelmú ajánlás arról, mely posztoperatív vérnyomásérték és hogyan, mennyire agresszíven kezelendő. Bouri és mtsai

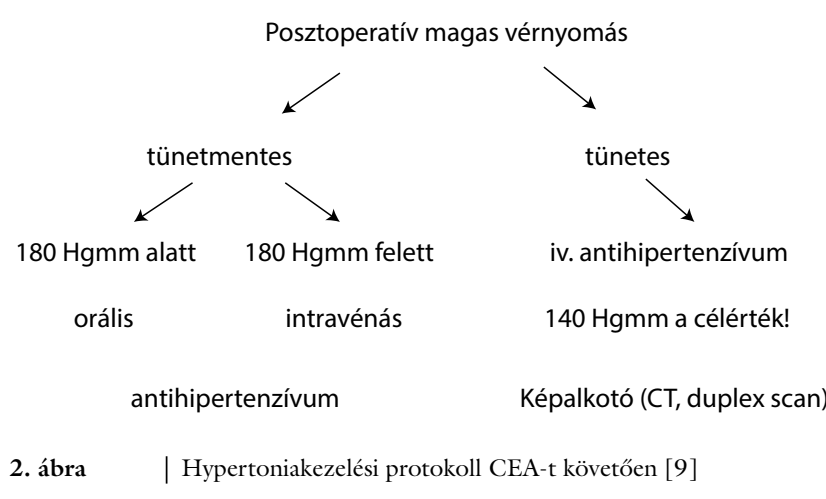

nagyszámú beteganyagon végzett elemzése nyomán azt mondhatjuk, hogy $180 \mathrm{Hgmm}$-t meghaladó tenzió esetén a kockázat $80 \%$ feletti, $140 \mathrm{Hgmm}$ alatt pedig elenyésző a CHS kialakulására nézve [9]. Választóvonalnak tekintendő a $150 \mathrm{Hgmm}$-es vérnyomás, amely felett exponenciálisan nő a kockázat [9]. Meg kell különböztetnünk a tünetekkel és a nélkülük jelentkező magas vérnyomást a terápia megválasztásához $[8,9]$. Általánosságban elmondható, hogy a tünetmentes esetek döntóen per orális szerekkel, míg a tünetes betegek csak intravénásan adandó szerekkel kezelhetőek, kezelendőek [8,9]. Ez utóbbi esetben hosszabb intenzív osztályos kezelés, további vizsgálatok is szükségesek [9] (2. ábra). Mivel az első 24 órában 74\%-ban jelentkezik instabil vérnyomás [1], és a betegek közel egyharmadánál jelentkezik posztoperatív hypertonia [1], ezért mindenképp javasolt intenzív monitorozás, megfigyelés ebben az időszakban [19], ugyanis a szükséges reakció késésének következménye végzetes is lehet. Amennyiben a vérnyomás stabilizálódik (gyakorlatunkban stabilan $140 \mathrm{Hgmm}$ alatti) amelynek gondos beállításához kardiológus bevonása is ajánlott - és a beteg panaszmentes, akkor emittálható [9]. Gyakori vérnyomás-ingadozás, iv. gyógyszer adásának igénye esetén igen szoros tenziókontroll javasolt, esetleg 1 hétre ambuláns vérnyomásmonitor felhelyezése mérlegelendő [9]. Ismételten tapasztalt kiugró érték esetén azonnali rehospitalizáció, belgyógyászati megfigyelés és kivizsgálás szükséges [9]. Megfelelő diagnózis és kezelés mellett a $80 \%$-ot is meghaladja a maradványtünet nélkül gyógyult betegek száma, azonban az intracerebralis haemorrhagia halálozása az $50 \%$-ot is eléri [1].

\section{Következtetések}

A cerebralis hyperperfusiós szindróma ritka, olykor azonban súlyos szövődményekben megnyilvánuló kórkép. Kialakulásának megelőzésében legfontosabb feladatunk az egyetlen gyógyszeresen befolyásolható rizikófaktor, a hypertonia megfelelő preoperatív beállítása, műtét alatti kontrollja és műtét utáni monitorozása; illetve kialakult tünetek esetén a mielőbbi, adekvát, kellően agresszív terápia. 
Anyagi támogatás: A közlemény megírása anyagi támogatásban nem részesült.

Szerzôi munkamegosztás: Minden szerző az érintett betegek ellátásában végzett munkájával járult hozzá a kézirat elkészítéséhez. A kézirat megszövegezésében dr. Menyhei Gábor nyújtott segítséget. A cikk végleges változatát valamennyi szerző elolvasta és jóváhagyta.

Érdekeltségek: A szerzőknek nincsenek érdekeltségeik.

\section{Irodalom}

[1] Adhiyaman, V., Alexander, S.: Cerebral hyperperfusion syndrome following carotid endarterectomy. QJM, 2007, 100(4), 239-244.

[2] Chaturvedi, S., Bruno, A., Feasby, T., et al.: Carotid endarterctomy - an evidence based review. Report of the Therapeutics and Technology Assessment Subcommittee of the American Academy of Neurology. Neurology, 2005, 65(6), 794-801.

[3] Liapis, C. D., Bell, P. R., Mikbailidis, D., et al.: ESVS guidelines. Invasive treatment for carotid stenosis: indications, techniques. Eur. J. Vasc. Endovasc. Surg., 2009, 37(4Suppl.), S1-S19.

[4] Menyhei, G., Björck, M., Beiles, B., et al.: Outcome following carotid endarterectomy: lessons learned from a large international vascular registry. Eur. J. Vasc. Endovasc. Surg., 2011, 41(6), 735-740.

[5] Sundt, T. M. Jr., Sharbrough, F. W., Piepgras, D. G., et al.: Correlation of cerebral blood flow and electroencephalographic changes during carotid endarterectomy: with results of surgery and hemodynamics of cerebral ischemia. Mayo Clin. Proc., 1981, 56(9), 533-543.

[6] Wylie, E. J., Hein, M. F., Adams, J. E.: Intracranial haemorrhage following surgical revascularization for treatment of acute strokes. J. Neurosurg., 1964, 21(3), 212-215.

[7] Naylor, A. R., Evans, J., Thompson, M. M., et al.: Seizures after carotid endarterectomy: hyperperfusion, dysautoregulation or hypertensive encephalopaty? Eur. J. Vasc. Endovasc. Surg., 2003, 26(1), 39-44.

[8] Newman, J. E., Ali, M., Sharpe, R., et al.: Changes in middle cerebral artery velocity after carotid endarterectomy do not identify patients at high-risk of suffering intracranial haemorrhage or stroke due to hyperperfusion syndrome. Eur. J. Vasc. Endovasc. Surg., 2013, 45(6), 562-571.

[9] Bouri, S., Thapar, A., Shalhoub, J. et al.: Hypertension and the post-carotid endarterectomy cerebral hyperperfusion syndrome. Eur. J. Vasc. Endovasc. Surg., 2011, 41(2), 229-237.
[10] Piepgras, D. G., Morgan, M. K., Sundt, T. M. Jr., et al.: Intracerebral hemorrhage after carotid endarterectomy. J. Neurosurg., $1988,68(4), 532-536$.

[11] Lewis, S. C., Warlow, C. P., Bodenham, A. R., et al.: General anaesthesia versus local anaesthesia for carotid surgery (GALA): a multicentre, randomised controlled trial. Lancet, 2008, 372(9656), 2132-2142.

[12] Nielsen, M. Ү., Sillesen, H. H., Jørgensen, L. G., et al.: The haemodynamic effect of carotid endarterectomy. Eur. J. Vasc. Endovasc. Surg., 2002, 24(1), 53-58.

[13] Jansen, C., Sprengers, A. M., Moll, F. L., et al.: Prediction of intracerebral haemorrhage after carotid endarterectomy by clinical criteria and intraoperative transcranial doppler monitoring: results of 233 operations. Eur. J. Vasc. Surg., 1994, 8(2), 220225.

[14] Yoshimoto, T., Shirasaka, T., Yoshizumo, T., et al.: Evaluation of carotid distal pressure for prevention of hyperperfusion after carotid endarterectomy. Surg. Neurol., 2005, 63(5), 554-557.

[15] Ascher, E., Markevich, N., Schutzer, R. W., et al.: Cerebral hyperperfusion syndrome after carotid endarterectomy: predictive factors and hemodynamic changes. J. Vasc. Surg., 2003, 37(4), 769-777.

[16] Feigin, V. L., Anderson, N., Rinkel, G. J., et al.: Corticosteroids for aneurysmal subarachnoid haemorrhage and primary intracerebral haemorrhage. Cochrane Database Syst. Rev., 2005, 3, CD004583.

[17] Bereczki, D., Liu, M., Prado, G. F., et al.: Cochrane report: a systematic review of mannitol therapy for acute ischemic stroke and cerebral parenchymal hemorrhage. Stroke, 2000, 31(11), 27192722.

[18] Kiss, I. (ed.): Professional and organizational guideline for the treatment of hypertension in adults and children. Position statement of the Hungarian Hypertension Society, 2009. [A hypertoniabetegség felnőttkori és gyermekkori kezelésének szakmai és szervezeti irányelvei. A Magyar Hypertonia Társaság állásfoglalása és ajánlása 2009.] https://www.doki.net/tarsasag/hypertension/upload/hypertension/document/a_hypertonia_betegseg_felnottkori_es_gyermekkori_kezelesenek_szakmai_es_szervezeti_iranyelvei_2009.pdf [Hungarian]

[19] Angiology Guideline. Vascular surgery methodological letter 2009. [Angiológiai útmutató. Érsebészeti metodikai levél 2009.] http://www.iranyelvek.hu/iranyelvek/old/all/angiologia/ Ersebeszeti\%20metodikai\%20level.pdf [Hungarian]

(Fazekas Gábor dr., Pécs, Madách I. u. 3/A, 7623 e-mail: drfazekasg@gmail.com) 